\title{
KESALAHAN PENGGUNAAN KALIMAT EFEKTIF PADA TUGAS KETERAMPILAN MENULIS KARANGAN EKSPLANASI SISWA KELAS XI IPS SMA NEGERI 3 KOTA JAMBI
}

\author{
Sainil Amral ${ }^{1}$, Waode Apria Dega Gaputri ${ }^{2}$ \\ Program Studi Pendidikan Bahasa dan Sastra Indonesia, \\ Fakultas Keguruan dan Ilmu Pendidikan, Universitas Batanghari, \\ Jambi \\ amralsainil@gmail.com \\ waodeapriadegagaputri@gmail.com
}

\begin{abstract}
The purpose of this study was to describe the use of effective sentence errors based on the characteristics of effective sentences in explanatory essays of class XI IPS 2 Semester 1 SMA N 3 Kota Jambi Academic Year 2019. This study included descriptive qualitative research. The primary data in this study isseries of sentences that are identified as violating the characteristics of effective sentence use, while the secondary data in this study are supporting data originating from books. Based on the results of the study it can be concluded that the wrong sentences are identified for violating the characteristics of effective sentences in explanatory essays of class XI IPS students semester 1 SMA N 3 Kota Jambi Academic Year 2019 based on four characteristics of effective sentences namely unity, economics, emphasis, and variance. Of the four characteristics, there are errors in the characteristics of the use of effective sentences that are dominant to errors found in the characteristics of unity and economics, while emphasis and variance are not too dominant. From the results of this study, researchers can suggest that writers pay more attention to effective sentences in writing essays and other writings.
\end{abstract}

Keywords: Effective Sentence, Explanatory

\footnotetext{
${ }^{1}$ Dosen Program Studi Pendidikan Bahasa dan Sastra Indonesia Fakultas Keguruan dan Ilmu Pendidikan Universitas Batanghari Jambi

${ }^{2}$ Mahasiswa Program Studi Pendidikan Bahasa dan Sastra Indonesia Fakultas Keguruan dan Ilmu Pendidikan Universitas Batanghari Jambi
} 


\section{PENDAHULUAN}

Pembelajaran Bahasa Indonesia merupakan salah satu kegiatan untuk melatih siswa terampil berbahasa agar mampu menuangkan ide dan gagasannya secara kreatif dan kritis (Setia, Erlina Zahar, dan Ade Rahima, 2018:183). Dalam pembelajaran bahasa Indonesia siswa diharuskan untuk memahami dan menguasai keterampilan dalam berbahasa. "Keterampilan berbahasa terdiri dari empat keterampilan, yaitu keterampilan menyimak/mendengarkan, keterampilan berbicara, keterampilan membaca, dan keterampilan menulis. Keempat keterampilan tersebut pada dasarnya merupakan satu kesatuan, yang disebut catur tunggal (Dawson dalam Tarigan, 1963:27).” Berdasarkan pengamatan penulis di SMA Negeri 3 Kota Jambi, keterampilan menulis menjadi sebuah permasalahan yang ada dalam keterampilan berbahasa. Oleh karena itu, keterampilan menulis menjadi hal yang sangat penting untuk dikuasai. Hal tersebut senada dengan pendapat Rofii dkk. (2019) “Writing skill is one of four language skills that must be mastered by students (Keterampilan menulis merupakan salah satu dari empat keterampilan berbahasa yang harus dikuasai oleh mahasiswa).

Keterampilan menulis sangat dibutuhan bagi siswa agar terampil menulis, maka dari itu, keterampilan menulis tidak kalah penting dari pembelajaran keterampilan berbahasa lainnya. Rofii dkk. (2019) mengatakan bahwa "Writing is one of the language abilities that must be mastered by students (Salah satu keterampilan berbahasa yang harus dikuasai oleh mahasiswa adalah keterampilan menulis)". Keterampilan pertama, "Menyimak atau mendengarkan adalah suatu proses kegiatan mendengarkan informasi atau cerita dengan penuh perhatian, pemahaman, apresiasi, serta interpretasi untuk memperoleh pesan serta memahami makna komunikasi yang disampaikan oleh seseorang (Tarigan, 1985: 29).”

Keterampilan kedua yang harus dikuasai siswa adalah keterampilan berbicara. Tarigan (1979: 3) mengatakan bahwa, "Berbicara adalah suatu kegiatan dalam mengeluarkan ide atau gagasan melalui lambang bunyi yang mengandung makna yang dapat dipahami.” Selanjutnya, Keterampilan ketiga, "Membaca adalah suatu proses kegiatan yang dilakukan dengan cara membaca sebuah paragraf atau kalimat untuk menemukan ide-ide atau pesan dari bacaan tersebut (Tarigan, 1979: 7).”

Keterampilan keempat adalah menulis, "Keterampilan menulis merupakan kesempatan yang memungkinkan penulis mengekspresikan diri, menyampaikan ide, dan menanggapi pendapat orang lain (Joseph F. Trimer dalam Barnawi dan Arifin, 2016: 15).” Oleh karena itu, keterampilan menulis membutuhkan pengetahuan yang luas agar tulisan yang dihasilkan dapat dibaca oleh pembaca dengan mengungkapkan gagasan seperti bercakap-cakap

Menurut Maimunah (2007: 24) "Kalimat efektif adalah kalimat yang dapat mengungkapkan gagasan penutur atau penulis secara tepat sehingga dapat dipahami oleh pendengar atau pembaca secara tepat pula sehingga pendengar atau pembaca dapat memahami pikiran tersebut dengan mudah, jelas, dan lengkap seperti apa yang dimaksud oleh penulis atau pembicaranya." Dapat disimpulkan bahwa, kalimat efektif mampu menyampaikan pesan kepada pendengar atau penulis kepada pembaca dengan tepat, singkat, jelas, dan padat sehingga akan muncul persamaan ide, perasaan, pikiran, dan gagasan antara pembicara kepada pendengar atau penulis kepada pembaca. 
Kemudian penyampaiannya harus memenuhi syarat sebagai kalimat yang efektif, yaitu strukturnya yang benar, ciricirinya, pilihan katanya yang tepat, dan ejaannya harus benar. Oleh karena itu, kalimat efektif menjadi bagian penting dalam penulisan sebuah karangan. Karangan adalah suatu tulisan ilmiah atau kegiatan komunikatif antara penulis dengan pembaca yang disusun dengan menggunakan rangkaian kata sehingga menjadi sebuah kalimat, paragraf, dan akhirnya menjadi wacana yang dibaca serta mudah dipahami.

Berdasarkan pengamatan penulis, saat penulis melaksanakan praktek pengalaman lapangan (PPL) di SMA Negeri 3 Kota Jambi kelas XI IPS 2 ternyata masih banyak kesalahan pengunaan dalam penulisan kalimat efektif. Misalnya, kalimat pelangi hanya akan Nampak apabila antara pengamat dan hujan yang bersamaan dengan matahari yang bersinar berada di sisi yang berlawanan. Penggunaan kata apabila dan antara pada kalimat itu tidak tepat, karena kedua kata itu memiliki arti atau makna yang sama yaitu menyatakan waktu. Penempatan kata pengamat dan hujan menjadi kata yang ambigu karena pengamat dan hujan lebih

menunjukan kepada kata yang berbeda, yang mana pengamat menyatakan "orang yang sedang meneliti sedangkan hujan menyatakan "fenomena alam". Perbaikan kalimat tersebut ialah pelangi hanya akan nampak apabila hujan dan matahari yang bersinar secara bersamaan berada di sisi yang berlawanan.

Ruang lingkup karangan yang dipelajari siswa SMA kelas XI adalah karangan prosedur, eksplanasi, dan ceramah. Karangan eksplanasi adalah teks baru yang dikenalkan kepada siswa dengan kurikulum Revisi 2013. Oleh karena itu, teks eksplanasi belum ada dijadikan sebagai bahasan dalam skripsi.
Atas dasar itu, penulis memilih teks eksplanasi sebagai objek penelitian. Sesuai dengan alasan di atas, teks eksplanasi akan menjadi bahasan pokok dalam skripsi ini. "Teks eksplanasi merupakan teks yang menjelaskan proses terjadinya suatu fenomena alam, sosial, budaya, atau yang lainnya (Sobandi, 2016: 17).” Dapat disimpulkan teks eksplanasi bertujuan untuk memberikan informasi berupa penjelasan tentang proses bagaimana atau mengapa suatu fenomena dapat terjadi. Contohnya, teks proses terjadinya gerhana matahari atau teks proses terjadinya banjir. Seperti kebanyakan teks, teks eksplanasi tersusun atas beberapa struktur dan paragraf yaitu: penjelasan umum, sebab-akibat, dan interpretasi. Yang mana setiap paragraf haruslah memiliki kesepadanan agar tercapainya suatu tujuan.

Rofii dkk. (2018) mengatakan "Many students are difficult to write a wellestablished writing. Such difficulties include various levels of written language use asword choices (diction), sentence structures, paragraph developments, writing developments and the grammar rules (banyak mahasiswa yang mengalami kesulitan dalam menggunakan bahasa tulis, kesulitan tersebut mencakup berbagai tataran pemakaian bahasa tulis, yaitu: dalam pemilihan kata (diksi), penyusunan kalimat, pengembangan paragraf, pengembangan tulisan dan penerapan tata tulis." Kendala yang sering dialami siswa dalam menulis teks eksplanasi mencakup beberapa faktor. Faktor-faktor penyebabnya adalah siswa kurang membaca, kuranganya keinginan atau minat dalam menulis, dan yang tidak kalah penting adalah sudah menjadi sebuah kebiasaan siswa serta menganggap bahwa tugas menulis tidaklah penting.

Berdasarkan latar belakang di atas, dapat diidentifikasikan bahwa kajian ini sangat luas. Oleh karena itu penulis akan menjabarkan pendapat ahli yang 
memiliki beberapa kesamaan pendapat tentang kalimat efektif. Salah satu teori ahli tersebut akan dikemukakan oleh Putrayasa (2014: 47) yang menyatakan bahwa, "Kalimat Efektif dapat dibedakan berdasarkan berbagai kriteria atau sudut pandanng yaitu struktur kalimat efektif, ciri-ciri kalimat efektif, logika (penalaran dalam kalimat), faktor pendukung kalimat efektif, dan faktor penyebab ketidakefektifan kalimat.” Dalam kenyataannya untuk mengaplikasikan keempat syarat kalimat efektif tersebut akan terjadi berbagai kesalahan.

Berdasarkan identifikasi masalah, penulis menyadari luasnya objek kajian dan juga keterbatasan penulis dari berbagai aspek. Dengan demikian, penulis hanya fokus terhadap Kesalahan Penggunaan Ciri-ciri Kalimat Efektif Tugas Keterampilan Menulis Karangan Eksplanasi Siswa Kelas XI IPS 2 Semester 1 SMA Negeri 3 Kota Jambi Tahun Ajaran 2019.

Berdasarkan fokus penelitian di atas, maka pertanyaan penelitian adalah bagaimanakah kesalahan penggunaan ciri-ciri kalimat efektif tugas keterampilan menulis karangan eksplanasi siswa kelas XI IPS 2 Semester 1 SMA Negeri 3 Kota Jambi Tahun Ajaran 2019?

Adapun tujuan dalam penelitian ini yaitu untuk mendeskripsikan kesalahan penggunaan kalimat efektif pada tugas keterampilan menulis karangan eksplanasi siswa kelas xi ips 2 semester 1 SMA Negeri 3 Kota Jambi Tahun Ajaran 2019.

\section{METODE PENELITIAN}

Jenis penelitian ini adalah adalah penelitian kualitatif yang mengacu pada kebahasaan dan menggunakan pendekatan deskriptif kualitatif. Bogdan, Taylor, dan Fatchan dalam Martha dan Kresno (2016: 2) menyatakan bahwa,
"Pendekatan deskriptif merupakan suatu metode penelitian yang diharapkan dapat menghasilkan suatu deskripsi tentang ucapan, tulisan, atau perilaku yang dapat diamati dari suatu individu, kelompok, masyarakat atau organisasi tertentu dalam suatu keadaan atau tata cara yang tertentu pula." Uraian tersebut mengatakan pendekatan deskriptif tentunya dapat dijadikan penelitian kualitatif, seperti yang akan dilakukan oleh penulis.

Penelitian kualitatif dilakukan oleh para peneliti dalam bidang ilmu sosial, perilaku, dan bahasa. "Penelitian kualitatif adalah peristiwa komunikasi atau berbahasa karena peristiwa ini melibatkan tuturan, makna semantik tutur, orang yang bertutur, maksud yang bertutur, situasi bertutur, peristiwa tutur, tindak tutur, dan latar tuturan (Muhammad, 2011: 31).” Dengan penelitian kualitatif, seorang peneliti dapat dengan mudah memahami komunikasi serta berbagai hal yang berhubungan dengan berbahasa karena didalamnya terdapat berbagai penjelasan makna.

Berdasarkan beberapa pendapat para ahli di atas, dapat penulis simpulkan bahwa pada penelitian ini metode yang penulis gunakan adalah metode deskriptif kualitatif. Metode deskriptif kualitatif adalah jenis penelitian kualitatif atau induktif yang lebih menekankan penjelasan yang mempunyai makna. Jenis penelitian ini penulis gunakan

Teknik pengumpulan data yang peneliti gunakan dalam penelitian ini adalah teknik observasi dan dokumentasi. 1. Observasi

Sutrisno dalam Sugiyono (2007: 203) mengatakan bahwa, "Observasi merupakan suatu proses yang kompleks, suatu proses yang tersusun dari berbagai proses biologis dan psikologis.” Teknik observasi digunakan bila penelitian 
berkenaan dengan perilaku manusia, proses kerja, gejala-gejala alam, dan responden yang diamati tidak terlalu besar. Dalam hal ini peneliti melakukan pengamatan terhadap proses pembelajaran siswa kelas XI IPS 2 semester 1 SMA Negeri 3 Kota Jambi.

2. Dokumentasi

Dalam mengumpulkan data secara fisik, peneliti menggunakan teknik dokumentasi. Dokumentasi yang dimaksudkan di sini dapat berupa tulisan, gambar, karya dari seseorang berupa monumental.

Pengumpulan data dalam penelitian ini menggunakan teknik dokumentasi yang difokuskan dalam menganalisis kesalahan penggunaan kalimat efektif tugas keterampilan menulis karangan eksplanasi siswa kelas XI IPS 2 semester 1 SMA Negeri 3 Kota Jambi Tahun Ajaran 2019.

Setelah semua data diperoleh, maka langkah berikutnya adalah menganalisis keseluruhan data. Patton dalam Muhammad (2011: 221) mengatakan bahwa, “ Analisis data merupakan suatu proses mengatur urutan data, mengorganisasikannya ke dalam suatu pola, kategori, dan satuan uraian dasar."

Langkah-langkah yang dilakukan peneliti dalam menganalisis data, adalah sebagai berikut:

1. Peneliti mengumpulkan semua data yang diperoleh berupa tugas keterampilan menulis karangan eksplanasi siswa kelas XI IPS 2 semester 1 SMA Negeri 3 Kota Jambi Tahun Ajaran 2019.

2. Peneliti memilah karangan eksplanasi siswa yang sesuai dengan ciri-ciri kalimat efektif.

3. Peneliti mencermati penulisan kalimat efektif pada setiap paragraf yang ada pada karangan eksplanasi siswa kelas XI IPS 2.

4. Peneliti menemukan ketidakefektifan kalimat pada karangan eksplanasi siswa kelas XI IPS 2.

5. Peneliti memasukkan bentuk-bentuk kesalahan penggunaan kalimat pada karangan eksplanasi siswa ke dalam tabel temuan.

6. Peneliti memaparkan bentuk-bentuk kesalahan penggunaan kalimat efektif pada karangan eksplanasi siswa yang terdapat dalam tabel temuan dan memperbaikinya.

7. Peneliti menyimpulkan hasil penelitian.

\section{HASIL DAN PEMBAHASAN}

Berdasarkan analisis data yang telah dilakukan terhadap kesalahan penggunaan ciri-ciri kalimat efektif pada karangan eksplanasi siswa kelas XI IPS 2 semester 1 SMA Negeri 3 Kota Jambi, maka dapat peneliti simpulkan bahwa teridentifikasikan kalimat-kalimat yang salah karena, melanggar ciri-ciri kalimat efektif pada karangan eksplanasi siswa, berdasarkan empat ciri kalimat efektif yaitu ciri kesatuan, kehematan, penekanan, dan kevariasian. Dari keempat ciri kesalahan penggunaan kalimat efektif tersebut yang dominan terhadap kesalahan terdapat pada ciri kesatuan dan kehematan sedangkan penekanan dan kevariasian tidak terlalu dominan.

Penelitian ini membahas tentang analisis kesalahan penggunaan kalimat efektif tugas keterampilan menulis karangan eksplanasi Siswa Kelas XI IPS 2 Semester 1 SMA Negeri 3 Kota Jambi Tahun Ajaran 2019. Berdasarkan hasil penelitian yang telah dikemukakan dan dijabarkan bahwa kesalahan penggunaan kalimat efektif pada karangan eksplanasi siswa terdapat empat ciri kalimat efektif. 
Empat ciri kalimat efektif ini akan dideskripsikan sebagai berikut.

\section{Analisis Ciri Kesatuan Kalimat Efektif pada Karangan Eksplanasi Siswa}

Syarat pertama dalam kalimat efektif adalah adanya kesatuan gagasan, ide pokok, atau satu kesatuan pikiran yang mana setiap kalimat harus saling mendukung sehingga membentuk satu kesatuan yang utuh. Kesatuan bisa dibentuk jika ada keselarasan antara subjek-predikat, predikat-objek, dan predikat-keterangan (Putrayasa, 2014: 54).

Berikut adalah beberapa kutipan yang menyatakan kesalahan ciri kesatuan penggunaan kalimat efektif pada karangan eksplanasi siswa kelas XI IPS 2 semester 1 SMA Negeri 3 Kota Jambi Tahun Ajaran 2019:

\section{(1.1) "Sampah adalah suatu} benda yang telah tidak dimanfaatkan lagi (siswa MW).”

Kutipan (1.1) Kalimat siswa MW dinyatakan tidak sesuai dengan kalimat efektif, karena kutipan tersebut tidak memiliki ciri kesatuan. Kalimat tersebut tidak memiliki kepaduan atau keselarasan dalam kalimat. Seharusnya partikel telah dihilangkan. Perbaikannya adalah sebagai berikut "Sampah adalah suatu benda yang tidak dimanfaatkan lagi.”

(1.2) "Rokok juga mengandung nikotin dan bahan berbahaya lainnya (Siswa NAS). Rokok terbuat dari tembakau yang digulung menggunakan kertas khusus." Kutipan (1.2) Siswa NAS dinyatakan tidak sesuai dengan kalimat efektif karena kutipan tersebut tidak memiliki ciri kesatuan. Kalimat rokok juga mengandung nikotin dan bahan berbahaya lainnya agar menjadi kalimat yang memiliki kesatuan yang utuh maka menjadi "Rokok mengandung nikotin dan bahan berbahaya lainnya."
Seharusnya menghilangkan kata juga, sehingga kalimat tersebut menjadi lebih jelas serta makna yang disampaikan kepada pembaca menjadi lebih mudah untuk dimengerti.

(1.3) "Selama ini pertumbuhan jumlah kendaraan meningkat pesat (Siswa ET)." Hampir semua jalan di Jakarta mengalami kemacetan yang cukup membuat kita pusing, kesel akibat macet yang terjadi. Faktor lain yang berperan dalam kemacetan adalah banyak pengendara yang tidak disiplin dan tidak mematuhi aturan yang berlaku serta jumlah penduduk DKI Jakarta yang semakin banyak.”

Kutipan (1.3) Kalimat siswa ET dinyatakan tidak sesuai dengan kalimat efektif karena kutipan tersebut tidak terdapat ciri kesatuan. Kalimat selama ini pertumbuhan jumlah kendaraan meningkat pesat agar menjadi kalimat yang memiliki kesatuan yang utuh maka menjadi "Selama ini jumlah kendaraan meningkat pesat." Seharusnya menghilangkan kata pertumbuhan, karena kata tersebut tidak tepat untuk menyatakan sebuah kendaraan yang jumlahnya meningkat. Kata pertumbuhan lebih tepat jika disandingkan dengan kalimat yang menyatakan makhluk hidup.

(1.4) "Percikan air hujan merupakan media utama pelepasan partikel tanah pada erosi yang disebabkan oleh air (Siswa RR). Karena, gravitasi bumi partikel tersebut jatuh kembali ke bumi."

Kutipan (1.4) Kalimat siswa RR dinyatakan tidak sesuai dengan kalimat efektif karena kutipan tersebut tidak terdapat ciri kesatuan. Kalimat percikan air hujan merupakan media utama pelepasan partikel tanah pada erosi yang disebabkan oleh air, Agar menjadi kalimat yang memiliki kesatuan yang 
utuh maka menjadi "Jatuhnya air hujan merupakan media utama pelepasan partikel tanah pada erosi." Seharusnya menghilangkan beberapa kata yaitu percikan, yang disebabkan oleh air dan digantikan dengan kata yang dianggap lebih tepat pada kalimat tersebut.

\section{Analisis Ciri Kehematan Kalimat Efektif pada Karangan Eksplanasi Siswa}

Unsur terpenting lainnya yang perlu diperhatikan dalam pembentukan kalimat efektif adalah kehematan. Kalimat yang dikatakan hemat bukan karena katanya yang terlalu sedikit malainkan jumlah kata yang terlalu banyak. Kehematan adalah adanya hubungan jumlah kata yang digunakan dengan luasnya jangkauan makna yang diacu (Putrayasa 2014: 55).

Berikut ini adalah sebagian kutipan yang menyatakan kesalahan ciri kehematan penggunaan kalimat efektif pada karangan eksplanasi siswa kelas XI IPS 2 semester 1 SMA Negeri 3 Kota Jambi Tahun Ajaran 2019:

(2.1) "Kekeringan tentu saja menyebabkan kegiatan masyarakat terganggu seperti mencuci, memasak, mandi, dan sebagainya (Siswa RRG).”

Kutipan (2.1) Kalimat siswa RRG dinyatakan tidak sesuai dengan kalimat efektif karena kutipan tersebut tidak memiliki ciri kehematan dalam menggunakan kata yang singkat, padat, dan jelas. Kalimat tersebut memakai kata-kata yang dianggap tidak perlu lagi digunakan. Perbaikannya "Kekeringan tentu menyebabkan kegiatan masyarakat terganggu seperti mencuci, memasak, mandi, dan sebagainya.” Kata yang penulis anggap tidak perlu lagi digunakan adalah saja. Menurut penulis kata tersebut tidak hemat karena terdapat pengulangan subjek kalimat.

mengkonsumsi

$$
\text { “Adapun manfaat }
$$
makanan sehat bagi tubuh kita yaitu, agar berkembang dan kesehatan tubuh benar-benar terjaga. Namun kebanyakan orang tidak menyadari bagaimana makanan tidak sehat yang dikonsumsi setiap harinya dan lama kelamaan akan menimbulkan penyakit (Siswa VSY)."

Kutipan (2.2) Kalimat siswa VSY dinyatakan tidak sesuai dengan kalimat efektif karena kutipan tersebut tidak memiliki ciri kehematan dalam menggunakan kata yang singkat, padat, dan jelas. Kalimat tersebut memakai kata-kata yang dianggap tidak perlu lagi digunakan. Perbaikannya "Namun kebanyakan orang tidak menyadari bagaimana makanan tidak sehat yang dikonsumsi setiap hari dan kelamaan akan menimbulkan penyakit.” Partikel dan kata yang penulis anggap tidak perlu lagi digunakan adalah nya pada harinya dan lama. Menurut penulis partikel dan kata tersebut tidak hemat karena terdapat pengulangan subjek kalimat.

(2.3) "Hujan yang saya amati ditandai dengan datangnya kumpulan awan abu-abu di langit yang lama kelamaan warnanya berubah menjadi cenderung kehitaman (Siswa RJ). Sekitar 30 menit kemudian, hujan turun.”

Kutipan (2.3) Kalimat siswa RJ dinyatakan tidak sesuai dengan kalimat efektif karena kutipan tersebut tidak memiliki ciri kehematan dalam menggunakan kata dan tidak terbelitbelit. Kalimat tersebut memakai kata-kata yang dianggap tidak perlu lagi digunakan, agar menjadi kalimat yang hemat serta jelas perbaikannya "Hujan yang saya amati ditandai dengan datangnya kumpulan awan abu-abu di 
langit yang lama kelamaan berubah menjadi kehitaman.” Kata yang penulis anggap tidak perlu lagi digunakan adalah warnanya berubah menjadi cenderung. Menurut penulis kata tersebut tidak hemat karena terdapat hiponim. Seperti abu-abu dan kehitaman menyatakan warna sehingga di dalam kalimat tersebut tidak perlu lagi menggunakan kata warna.

(2.4) "Gunung meletus terjadi disebabkan oleh adanya endapan magma yang berada dalam perut bumi (Siswa RDS). Letusan gunung berapi adalah salah satu bencana alam yang sangat besar dan luar biasa."

Kutipan (2.4) Kalimat siswa RDS dinyatakan tidak sesuai dengan kalimat efektif karena kutipan tersebut tidak memiliki ciri kehematan dalam menggunakan kata yang singkat, padat, dan jelas. Kalimat tersebut memakai kata-kata yang dianggap tidak perlu lagi digunakan, agar menjadi kalimat yang hemat serta jelas perbaikannya "Gunung meletus disebabkan oleh endapan magma yang berada dalam perut bumi." Kata yang penulis anggap tidak perlu lagi digunakan adalah terjadi dan adanya. Menurut penulis kata tersebut memiliki kesamaan arti sehingga jika digunakan maka kalimat tersebut akan menjadi kalimat yang tidak hemat.

\section{Analisis Ciri Penekanan dalam Kalimat Efektif pada Karangan Eksplanasi Siswa}

Unsur terpenting lainnya yang perlu diperhatikan dalam pembentukan kalimat efektif adalah penekanan. "Yang dimaksud dengan penegasan dalam kalimat adalah upaya pemberian aksentuasi, pementingan atau pemusatan perhatian pada salah satu unsur atau bagian kalimat, agar unsur atau bagian kalimat yang diberi penegasan itu lebih mendapat perhatian dari pendengar atau pembaca (Putrayasa, 2014: 56).”

Berikut adalah sebagian kutipan yang menyatakan kesalahan ciri penekanan dalam penggunaan kalimat efektif pada karangan eksplanasi siswa kelas XI IPS 2 semester 1 SMA Negeri 3 Kota Jambi Tahun Ajaran 2019:

$\begin{array}{llc}\text { (3.1) } & \text { "Tapi kadang-kadang } \\ \text { aurora } & \text { muncul } & \text { di puncak } \\ \text { gunung } & \text { di iklim } & \text { tropis }\end{array}$

(Siswa EAK). Fenomena aurora disebelah Selatan yang dikenal aurora Australis mempunyai sifat-sifat yang serupa."

Kutipan (3.1) Kalimat siswa EAK dinyatakan tidak sesuai dengan kalimat efektif, karena kalimat tersebut tidak memiliki ciri penekanan dalam kalimat. Agar kalimat tersebut memiliki penekanan, maka kalimat haruslah diberi penegasan atau pemusatan untuk mendapatkan perhatian khusus dari pembaca. Perbaikannya menjadi "Terkadang Aurora memang muncul di puncak gunung iklim tropis."

(3.2) "Supermoon adalah saat bulan paling dekat ke Bumi (Siswa LSA)."

Kutipan (3.2) Kalimat siswa LSA dinyatakan tidak sesuai dengan kalimat efektif, karena kalimat tersebut tidak memiliki ciri penekanan dalam kalimat. Agar kalimat tersebut memiliki penekanan, maka kalimat haruslah diberi penegasan atau pemusatan untuk mendapatkan perhatian khusus dari pembaca. Perbaikannya menjadi "Supermoon adalah suatu peristiwa ketika posisi bulan berada pada jarak terdekat dengan bumi."

(3.3) "Fenomena ini jarang terjadi karena hanya satu kali dalam 14 bulan sebagian orang percaya bahwa supermoon dapat menimbulkan bencana alam seperti gempa bumi, tsunami, dan pasang surut air laut. Sehingga 
tidak sedikit orang yang percaya dan merasa takut akan fenomena ini (Siswa RK)."

Kutipan (3.3) Kalimat siswa RK dinyatakan tidak sesuai dengan kalimat efektif, karena kalimat tersebut tidak memiliki ciri penekanan dalam kalimat. Agar kalimat tersebut memiliki penekanan, maka kalimat haruslah diberi penegasan atau pemusatan untuk mendapatkan perhatian khusus dari pembaca. Perbaikannya menjadi "Memang tidak sedikit orang yang percaya dan takut akan fenomena supermoon ini."

(3.4) "Untuk lebih maksimal dalam mengurangi jumlah kecelakaan adalah dengan mematuhi rambu lalu lintas (Siswa B).”

Kutipan (3.4) Kalimat siswa B dinyatakan tidak sesuai dengan kalimat efektif, karena kalimat tersebut tidak memiliki ciri penekanan dalam kalimat. Agar kalimat tersebut memiliki penekanan, maka kalimat haruslah diberi penegasan atau pemusatan untuk mendapatkan perhatian khusus dari pembaca. Perbaikannya menjadi "Mematuhi rambu lalu lintas adalah cara maksimal dalam mengurangi jumlah kecelakaan.”

\section{Analisis Ciri Kevariasian Kalimat Efektif pada Karangan Eksplanasi Siswa}

Unsur terpenting terakhir yang perlu diperhatikan dalam pembentukan kalimat efektif adalah kevariasian. Kelincahan dalam penulisan tergambar dalam struktur kalimat yang dipergunakan. Kevariasian ini tidak bisa kita temukan dalam kalimat demi kalimat, atau pada kalimat-kalimat yang dianggap sebagai struktur bahasa yang berdiri sendiri. Ciri kevariasian akan diperoleh jika kalimat yang satu dibandingkan dengan kalimat yang lain (Putrayasa, 2014: 65).

Berikut adalah sebagian kutipan yang menyatakan kesalahan ciri kevariasian penggunaan kalimat efektif pada karangan eksplanasi siswa kelas XI IPS 2 semester 1 SMA Negeri 3 Kota Jambi Tahun Ajaran 2019:

(4.1) "Efek negatif rokok bisa jangka pendek atau jangka panjang. Memang untuk berhenti ngerokok sangatlah tidak mudah, karena rokok mengandung senyawa yang membuat ketagihan (Siswa NAS).”

Kutipan (4.1) Kalimat siswa NAS dinyatakan tidak sesuai dengan kalimat efetif karena kutipan tersebut tidak memiliki ciri kevariasian. Seharusnya kevariasian kalimat harus tepat dalam memulai kalimat. Perbaikannya menjadi "Untuk berhenti merokok sangatlah tidak mudah, karena rokok mengandung senyawa yang membuat ketagihan.”

(4.2) "Terciptanya pelangi di cakrawala yaitu melalui empat siklus (Siswa R). Diantaranya yaitu pembiasan sinar matahari”

Kutipan (4.2) Kalimat siswa R dinyatakan tidak sesuai dengan kalimat efetif karena kutipan tersebut tidak memiliki ciri kevariasian. Seharusnya kevariasian kalimat harus tepat dalam memulai kalimat. Perbaikannya menjadi "Terciptanya pelangi di langit yaitu melalui empat siklus. Kevariasian dalam kalimat tersebut terdapat pada frasa keterangan cara yaitu adanya kata cakrawala pada kalimat tersebut.

(4.3) “Ikrar ini dianggap
sebagai
kristalisasi semangat
untuk menegaskan cita-cita
berdirinya Negara Indonesia (Siswa
RA). Sumpah pemuda adalah suatu
tonggak utama dalam sejarah
pergerakan kemerdekaan Indonesia.”


Kutipan (4.3) Kalimat siswa RA dinyatakan tidak sesuai dengan kalimat efetif karena kutipan tersebut tidak memiliki ciri kevariasian. Seharusnya kevariasian kalimat harus tepat dalam memulai kalimat. Perbaikannya menjadi "Ikrar ini dianggap sebagai penegasan semangat untuk menegaskan cita-cita berdirinya Negara Indonesia. Kevariasian dalam kalimat tersebut terdapat pada frasa keterangan cara yaitu adanya kata kristalisasi pada kalimat tersebut.

\section{SIMPULAN}

Berdasarkan hasil penelitian, maka dapat disimpulkan bahwa terdapat beberapa kesalahan penggunaan kalimat efektif pada karangan eksplanasi siswa kelas XI IPS 2 semester 1 SMA Negeri 3 Kota Jambi Tahun Ajaran 2019. Teridentifikasi kalimat-kalimat yang salah karena melanggar ciri-ciri kalimat efektif berdasarkan empat ciri kalimat efektif yaitu ciri kesatuan, kehematan, penekanan, dan kevariasian, sebagai berikut. Empat puluh enam ciri kesatuan, tiga puluh sembilan ciri kehematan, dua puluh sembilan ciri penekanan, dan lima ciri kevariasian sehingga total kesalahan penggunaan kalimat efektif pada karangan eksplanasi siswa kelas XI IPS 2 Semester 1 SMA Negeri 3 Kota Jambi Tahun Ajaran 2019 adalah seratus Sembilan belas kesalahan ciri kalimat efektif. Dari keempat ciri kesalahan penggunaan kalimat efektif tersebut yang dominan terhadap kesalahan terdapat pada ciri kesatuan dan kehematan sedangkan penekanan dan kevariasian tidak terlalu dominan.

\section{SARAN}

Berdasarkan hasil penelitian yang telah dijelaskan, maka dapat disarankan kepada beberapa pihak, sebagai berikut.
1. Kepada siswa, agar lebih teliti dalam membuat karangan baik itu dalam bentuk tulisan maupun lisan serta pelajari juga bagaimana penulisan kalimat yang efektif.

2. Disarankan bagi guru bahasa Indonesia, dapat memberikan pelajaran keterampilan menulis karangan eksplanasi dengan menggunakan kalimat yang efektif.

3. Disarankan kepada guru bahasa Indonesia sebaiknya mengajarkan materi kalimat efektif dan teks eksplanasi menggunakan teknik, metode, dan strategi pembelajaran yang menarik dan variatif.

4. Disarankan kepasa guru bahasa Indonesia agar lebih sering memberikan latihan kepada siswa sebagai pengaplikasian teori kalimat efektif yang telah dipelajari, agar siswa terbiasa menulis dengan baik dan benar.

5. Disarankan kepada peneliti selanjutnya, agar hasil penelitian ini dapat menjadi acuan bagi peneliti lain sebagai kajian yang sama dengan fokus permasalahan yang berbeda.

\section{DAFTAR PUSTAKA}

Ahmadi, Rulam. (2016). Metodologi Penelitian Kualitatif. Yogyakarta: Ar-Ruzz Media.

Arifin, M dan Barnawi. (2016). Teknik Penulisan Karya Ilmiah. Yogyakarta: Ar-Ruzz Media.

Danim, Sudarwan. (2002). Menjadi Penelitian Kualitatif. Bandung: CV. Pustaka Setia.

Maimunah, Siti Annijat. (2007). Buku Pintar Bahasa Indonesia (Untuk Pelajar, Mahasiswa, Dosen, dan Umum). Jakarta: Prestasi Pustakaraya.

Martha, Evi dan Sudarti Kresno. (2016). Metodologi Penelitian Kualitatif Untuk Bidang Kesehatan. 
Jakarta: PT. RajaGrafindo

Persada.

Muhammad. (2011). Metode Penelitian

Bahasa. Yogyakarta: Ar-

Ruzz Media.

Putrayasa, Ida Bagus. (2014). Kalimat Efektif (Diksi, Struktur, dan Logika). Bandung: Redaksi Reflika Aditama.

Rofii, A., Murtadho, F., Rahmat, A. (2018) "Model of ContextualBased Academic Writing Learning Module ( $R \& D$ At Faculty of Teacher Training And Education Universitas Batanghari Jambi)" English Review: Journal of English Education, vol. 6, no. 2 pp 51-60. Doi: $\quad 10.25134$ /erjee.v6i2.1242. (https://www.journal.uniku.ac.id/i ndex.php/ERJEE/article/view/124 $\underline{2}$

Rofii, Afif., Fathiaty, Murtadho., Rahmat, Aceng. (2019). Needs Analysis: A Learning Model for CTL-Based Academic Writing. Proceedings of the Eleventh Conference on Applied Linguistics (conaplin 2018) https://www.atlantispress.com/procedings/conaplin18/125911424

Rofii, Afif., Murtadho, Fathiaty., Rahmat, Aceng. (2019). The Perception of Lecturers and Students on Learning Model of Contextual-Based Academic Writing. Proceeding First International Conference on Advances in Education, Humanities, and Language. Malang: EAI

(https://eudl.eu/doi.418/eai.23-32019.2284915

Sugiyono. 2007. Metode Penelitian Pendidikan (Pendekatan
Kuantitatif, Kualitatif, dan $R \& D$ ). Bandung: $\quad$ Alfabeta.

Setia, R. B. J., Zahar, E., \& Rahima, A. (2018). "Penggunaan Media Lagu Pop dalam pembelajaran Menulis Cerpen Realis Siswa Kelas IX SMP Negeri 9 Kota Jambi Tahun Pelajaran 2016/2017”. Aksara: Jurnal Ilmiah Pendidikan Bahasa dan Sastra Indonesia, 2(1), 183191.

Tarigan, Henry Guntur 1985. Menyimak Sebagai Suatu

Keterampilan Berbahasa.

Bandung: Angkasa.

Tarigan, Henry Guntur. 1963. Berbicara Sebagai Suatu

Keterampilan Berbahasa.

Bandung: Angkasa.

Tarigan, Henry Guntur.1979. Membaca Sebagai Suatu Keterampilan Berbahasa. Bandung: Angkasa. 